\title{
Detection of titanium particles in human liver and spleen and possible health implications
}

\author{
M. B. Heringa ${ }^{1 *}$, R. J. B. Peters ${ }^{2}$, R. L. A. W. Bleys ${ }^{3}$, M. K. van der Lee², P. C. Tromp ${ }^{4}$, P. C. E. van Kesteren ${ }^{1}$, \\ J. C. H. van Eijkeren ${ }^{1}$, A. K. Undas ${ }^{2}$, A. G. Oomen ${ }^{1}$ and H. Bouwmeester 2,5
}

\begin{abstract}
Background: Titanium dioxide $\left(\mathrm{TiO}_{2}\right)$ is produced at high volumes and applied in many consumer and food products. Recent toxicokinetic modelling indicated the potential of $\mathrm{TiO}_{2}$ to accumulate in human liver and spleen upon daily oral exposure, which is not routinely investigated in chronic animal studies. A health risk from nanosized $\mathrm{TiO}_{2}$ particle consumption could not be excluded then.

Results: Here we show the first quantification of both total titanium ( $\mathrm{Ti}$ ) and $\mathrm{TiO}_{2}$ particles in 15 post-mortem human livers and spleens. These low-level analyses were enabled by the use of fully validated (single particle) inductively coupled plasma high resolution mass spectrometry ((sp)ICP-HRMS) detection methods for total Ti and $\mathrm{TiO}_{2}$ particles. The presence of $\mathrm{TiO}_{2}$ in the particles in tissues was confirmed by Scanning Electron Microscopy with energy dispersive $\mathrm{X}$-ray spectrometry.

Conclusions: These results prove that $\mathrm{TiO}_{2}$ particles are present in human liver and spleen, with $\geq 24 \%$ of nanosize $(<100 \mathrm{~nm})$. The levels are below the doses regarded as safe in animals, but half are above the dose that is deemed safe for liver damage in humans when taking into account several commonly applied uncertainty factors. With these new and unique human data, we remain with the conclusion that health risks due to oral exposure to $\mathrm{TiO}_{2}$ cannot be excluded.
\end{abstract}

Keywords: Titanium dioxide, Quantification, Human liver, Human spleen, Tissue level, Nanoparticle, Risk assessment, $\mathrm{Sp}-\mathrm{ICP}-\mathrm{HRMS}$

\section{Background}

Titanium dioxide $\left(\mathrm{TiO}_{2}\right)$ is produced as titanium white at high production volumes, up to 6 million tons per year [1]. It is incorporated in many products, such as in food (additive E171), toothpaste, supplements and medicines, as well as in applications like paints, plastics, and cosmetics [1]. Food grade $\mathrm{TiO}_{2}$ contains a fraction of particles in the nanosize range, which is around $10 \%$ number-based $[2,3]$. No acceptable daily intake (ADI) for oral ingestion of $\mathrm{TiO}_{2}$ has been derived in the past due to the absence of observed toxic effects in the available chronic rodent study [4], the generally assumed negligible

\footnotetext{
* Correspondence: minne.heringa@rivm.nl

${ }^{1}$ National Institute for Public Health and the Environment (RIVM), Bilthoven,

The Netherlands

Full list of author information is available at the end of the article
}

uptake of $\mathrm{TiO}_{2}$ following ingestion [5], and the assumed insolubility and inertness of the material $[6,7]$. Recent human volunteer studies, however, show elevated blood $\mathrm{Ti}$ levels (and indications of $\mathrm{TiO}_{2}$ particles) $6 \mathrm{~h}$ after ingestion of food grade $\mathrm{TiO}_{2}$ [8], confirming earlier reports of increased blood Ti-levels after ingestion of $160 \mathrm{~nm}$ and $380 \mathrm{~nm} \mathrm{TiO}_{2}$ particles [9]. Upon evaluating food grade $\mathrm{TiO}_{2}$, the European Food Safety Agency (EFSA) acknowledged that $\mathrm{TiO}_{2}$ is absorbed after oral application, albeit to a low extent, and transported to various organs [10]. Recently, very low oral (0.02 and $0.6 \%$ ) absorption of $\mathrm{TiO}_{2}$ nanoparticles has been shown in rats, with a retention of these particles in mainly the liver and spleen [11, 12]. This calls for (nano)particle biokinetic studies in humans [13]. 
Toxicokinetic modelling of $\mathrm{TiO}_{2}$ levels in human organs, based on animal studies and accounting for accumulation, has recently led to the conclusion that a human health risk from the oral intake of $\mathrm{TiO}_{2}$ nanoparticles cannot be excluded [14]. Although most accumulation was seen in spleen, in the final risk assessment, a potential risk was found for the liver. It remained uncertain whether the modelled levels of $\mathrm{TiO}_{2}$ nanoparticles for human liver and spleen are accurate, which is best verified by measurements. Although total-Ti has been detected before in human tissues like liver and spleen $[15,16]$, there currently are no data on the presence of $\mathrm{TiO}_{2}$ (nano)particles in human tissues from people without titanium implants $[17,18]$. Here, we present the first quantitative measurements of particles, both in size and concentration, in post-mortem liver and spleen of 15 human subjects (see Table 1) with a corresponding assessment of the risks that can potentially be associated with the observed total $\mathrm{Ti}$ and $\mathrm{TiO}_{2}$ particle concentrations in these tissues.

\section{Methods}

Firstly, we determined the total-Ti content in human liver and spleen samples using a fully validated procedure that included the acid digestion of the formaldehyde-fixed homogenized human tissues and ICP-HRMS detection (Peters RJB, Undas A, Memelink J, van Bemmel G, Munniks S, Bouwmeester $\mathrm{H}$, et al.: Development and validation of a method for the detection of titanium dioxide particles in human tissue, submitted). Next, a new, independent subsample was prepared to quantitatively determine the presence of $\mathrm{TiO}_{2}$ particles in these tissues.

Table 1 Overview of human subjects involved in this study

\begin{tabular}{lllll}
\hline Subject number & Gender (F/M) & Age (years) & Ethnicity & Ti implants \\
\hline 1 & F & 80 & Caucasian & No \\
2 & F & 92 & Caucasian & No \\
3 & M & 64 & Caucasian & Yes \\
4 & M & 86 & Caucasian & No \\
5 & M & 87 & Caucasian & No \\
6 & M & 79 & Caucasian & No \\
7 & F & 94 & Asian & No \\
8 & F & 77 & Caucasian & No \\
9 & F & 86 & Caucasian & No \\
10 & M & 77 & Caucasian & Yes \\
11 & F & 104 & Caucasian & No \\
12 & F & 96 & Caucasian & No \\
13 & F & 91 & Caucasian & No \\
14 & F & 94 & Caucasian & No \\
15 & M & 56 & Caucasian & No \\
\hline
\end{tabular}

For this, highly sensitive and selective spICP-HRMS was used [2, 19-21]. The enzymatic and gentle chemical sample clean-up and detection method for Ti in tissues and organs was recently fully validated (Peters RJB, Undas A, Memelink J, van Bemmel G, Munniks S, Bouwmeester H, et al.: Development and validation of a method for the detection of titanium dioxide particles in human tissue, submitted). The sample preparation is known not to affect the presence and size of particles [2].

\section{Samples and sample preparation}

The inertness of $\mathrm{TiO}_{2}$ allowed the use of livers (15) and spleens (15) obtained from bodies that were donated to the Department of Anatomy of the University Medical Centre Utrecht for educational and research purposes (Table 1). All ethical regulations concerning the use of these organs were followed, and approval for this specific scientific use was obtained from the board of University Medical Center Utrecht. The bodies, 6 men and 9 women who died at the age of 56 to 104 years, had been fixed in $4 \%$ formaldehyde. From these persons written informed consent was obtained during life that allowed the use of their entire bodies for educational and research purposes. While there is no information about their diets, it is known that all persons involved are of Caucasian ethnicity except one who was of Asian ethnicity. All have lived in the Netherlands their entire life and it is therefore assumed that most followed a Dutch diet [22]. Of the 15 persons involved, 2 received titanium implants during their lifetime. For sample preparation, each organ was cut into small pieces and grinded to a size of $0.5-1 \mathrm{~mm}$ diameter. To investigate potential sample contamination, all materials that had been in contact with the organs were collected. The total-Ti concentrations in these materials or released by these materials were determined. The average of the analytical results of those blank materials were calculated and subtracted from the sample results if they were above the limit of detection (LOD).

\section{Determination of total-Ti content}

An analytical sample of $1 \mathrm{~g}$ was collected from each grinded and homogenized sample and brought into a perfluoroalkoxy (PFA) microwave digestion tube to which $6 \mathrm{~mL}$ of nitric acid $\left(70 \% \mathrm{HNO}_{3}\right)$ and $2 \mathrm{~mL}$ of hydrofluoric acid (40\% HF), were added. All subsamples were digested for $55 \mathrm{~min}$ in a MARS microwave system (CEM Corporation, Matthews, NC, USA). The temperature program was as follows: at $1600 \mathrm{~W}$ power from 20 to $120{ }^{\circ} \mathrm{C}$ in $15 \mathrm{~min}$, then to $160{ }^{\circ} \mathrm{C}$ in $10 \mathrm{~min}$, and then to $210{ }^{\circ} \mathrm{C}$ in $30 \mathrm{~min}$ and hold for $1 \mathrm{~min}$. Following digestion and cooling to room temperature, ultra-pure water was added to a total volume of $50 \mathrm{~mL}$. The extracts were shaken manually, diluted 2 times, and analysed with ICP-HRMS. 
Quantification was based on ionic titanium standards diluted in the same acidic matrix as the samples. Method blanks were determined by performing the complete procedure, however, without the addition of a sample. The total-Ti content in the blanks was below the method LOD.

\section{Determination of $\mathrm{TiO}_{2}$ particles}

For the determination of particle- $\mathrm{TiO}_{2}$, a digestion procedure is followed to liberate the particles. This digestion procedure consists of two steps. In the first step, the tissue in the formaldehyde-fixed sample is depolymerized, while in the second step, a standard enzymatic digestion is performed. An analytical sample of $200 \mathrm{mg}$ was collected from the grinded subsamples and brought into a $12-\mathrm{mL}$ PE tube. In the first step, $4 \mathrm{~mL}$ of the digestion buffer was added and the sample was vigorously vortexed for $30 \mathrm{~s}$. The digestion buffer was prepared by dissolving $300 \mathrm{mg}$ of Tris buffer, $92.5 \mathrm{mg}$ EDTA, $5 \mathrm{mg}$ SDS and $3 \mathrm{~g} \mathrm{NaCl}$ in $100 \mathrm{~mL}$ of Milli-Q water. Next, $4 \mathrm{~g}$ of glycine are added to the solution and mixed with a magnetic stirrer until complete dissolution. This solution was diluted with Milli-Q water to a final volume of $250 \mathrm{~mL}$.

The tube was heated for $3 \mathrm{~h}$. at $100{ }^{\circ} \mathrm{C}$ to depolymerize the formaldehyde-fixed tissue. In the second step, and after cooling to room temperature, $910 \mu \mathrm{L}$ of proteinase $\mathrm{K}$ $(2.5 \mathrm{mg} / \mathrm{ml})$ was added. The tube was incubated for $16 \mathrm{~h}$. at $37^{\circ} \mathrm{C}$ in a shaking water bath. After cooling to room temperature, the digest was diluted with ultra-pure water and analyzed using sPICP-HRMS.

\section{Instrumental analysis with ICP-HRMS}

A Thermo Finnigan Element 2 (Thermo Fisher Scientific $\mathrm{GmbH}$, Bremen, Germany), a sector-field based high resolution ICP-MS, was used to measure total-Ti in acidic extracts in standard mode and $\mathrm{TiO}_{2}$ particles in single-particle mode (also called time resolved analysis mode). Single-particle ICP-HRMS is a method for the detection and characterization of (nano-)particles $[19,21]$. The Thermo Finnigan Element 2 was operated at a forward power of $1300 \mathrm{~W}$ and the argon gas flows were at the following settings; plasma, $15.4 \mathrm{~L} / \mathrm{min}$; nebulizer, $1.063 \mathrm{~L} / \mathrm{min}$; auxiliary, $1.2 \mathrm{~L} / \mathrm{min}$. The sample flow rate to the nebulizer was set at $0.5 \mathrm{~mL} / \mathrm{min}$. Data acquisition was done in standard mode and in time resolved analysis mode with titanium measured at $\mathrm{m} / \mathrm{z} 46.95$ in medium resolution mode to avoid interferences from ${ }^{36} \mathrm{Ar}^{12} \mathrm{C},{ }^{32} \mathrm{~S}^{16} \mathrm{O}$ and ${ }^{48} \mathrm{Ca}$. In standard and time resolved mode the dwell time was 250 and $2 \mathrm{~ms}$ respectively, with a total acquisition time of $60 \mathrm{~s}$. The transport efficiency was determined by the analyses of a $50 \mathrm{ng} / \mathrm{L}$ diluted aqueous RM8013 (60 nm gold nanoparticle) suspension under the same instrumental conditions as the samples but monitoring $m / z 197$ for gold. Finally, single-particle data were exported as csv file and processed in a dedicated spreadsheet for the calculation of particle sizes, particle size distributions, and particle number and mass concentrations. Details about this spreadsheet and the calculation of the parameters can be found elsewhere [19]. Method blanks were determined by performing the complete procedure, however, without the addition of a sample. The mass-based $\mathrm{TiO}_{2}$ particle concentrations in the blanks were below the method LOD. Since the blanks of the sampling materials were below the LOD of the total$\mathrm{Ti}$ method they were not involved in the particle analysis.

\section{LOD}

For the total-Ti determination the LOD is calculated as 3 times the standard deviation in the results of a blank sample or a sample with a total-Ti content close to the expected LOD. This sample is analysed on each of the validation days. The LOD is calculated as follows:

$$
L O D=3 \times \sqrt{\frac{\sum_{i=1}^{k}\left(y_{i}-m\right)^{2}}{k-1}}
$$

where $k$ is the number of samples, $y_{i}$ is the result of a single sample and $\mathrm{m}$ is average result of the single samples.

For particle- $\mathrm{TiO}_{2}$ there are two LOD values, one for the number- and mass-based concentration $\left(\mathrm{LOD}_{\mathrm{C}}\right)$, and one for particle size $\left(\mathrm{LOD}_{\mathrm{S}}\right)$. $\mathrm{LOD}_{\mathrm{C}}$ equals the minimum number of particle peaks in the time scan that differentiates a sample from a blank. A way to determine LOD $_{C}$ is by the IUPAC recommended approximation (Poisson) described as [23],

$$
L O D_{C}=3.29 \times \sqrt{N}+2.72
$$

where $\mathrm{N}$ is the number of particle peaks observed in the time scan of a blank. The particle number $\mathrm{LOD}_{\mathrm{C}}$ can be converted into mass units if the size and density of the particle are known. The determination of the $\mathrm{LOD}_{\mathrm{S}}$ is described by Lee et al. and can be estimated as follows [24],

$$
L O D_{S}=\sqrt[3]{\frac{6 \times 3 \sigma_{m}}{R \times f_{a} \times \rho \times \pi}}
$$

where $\sigma_{\mathrm{m}}$ is the standard deviation in the background noise in the time scan, R is the ICP-MS response (cps/ $\mu \mathrm{g}), f_{a}$ is the mass fraction of analysed element in the nanoparticle and $\rho$ is the density of the nanoparticle material $\left(\mathrm{g} / \mathrm{cm}^{3}\right)$. The upper size limit of detection is estimated to be around $1500 \mathrm{~nm}$. 


\section{Confirmation of $\mathrm{TiO}_{2}$ particles wit SEM-EDX}

Two subsamples of the grinded sample material of both the livers and the spleens were studied using scanning electron microscopy with energy dispersive $\mathrm{X}$-ray detection (SEM-EDX) to confirm the presence of $\mathrm{TiO}_{2}$ particles in human liver and spleen. The samples with the highest $\mathrm{TiO}_{2}$ concentrations (as determined with ICP-HRMS) were selected for confirmation with SEM-EDX. Typically, subsamples of $>100$ tissue grains were collected on a sampling stub and dried to remove water. These subsamples were analysed with a high resolution field emission gun scanning electron microscopy in combination with energy dispersive X-ray analysis (FEG-SEM/EDX). Approximately 500 images for each sample were viewed at different magnifications $(5.000-100.000 \mathrm{X})$ to identify $\mathrm{TiO}_{2}$ particles. For each sample, approximately 10 $\mathrm{TiO}_{2}$ particles (single nanoparticles as well as aggregates/agglomerates) were detected. The surface of the grains was systematically analysed for $\mathrm{TiO}_{2}$ particles using the backscattered electron imaging mode. After detection of particles in a field of view, X-ray spectra from the detected particle and surrounding matrix were acquired to determine the identity. Subsequently, plasma-ashing was applied to remove the lipid fraction and obtain a sharper image of the $\mathrm{TiO}_{2}$ particle.

\section{Results}

All tissue levels are given as wet organ weights as obtained after fixation in formaldehyde.

\section{Total Ti measurements}

As shown in Table 2, the total-Ti content in the liver ranged from 0.02 to $0.09 \mathrm{mg} \mathrm{Ti} / \mathrm{kg}$ tissue with an average value of $0.04 \pm 0.02 \mathrm{mg} \mathrm{Ti} / \mathrm{kg}$ tissue ${ }^{1}$. For spleen, the total-Ti content ranged from 0.02 to $0.4 \mathrm{mg} \mathrm{Ti} / \mathrm{kg}$ tissue with an average value of $0.08 \pm 0.1 \mathrm{mg} \mathrm{Ti} / \mathrm{kg}$ tissue ${ }^{1}$. In the sparsely available literature on human data, liver and spleen concentrations ranging between 0.2 and $1.9 \mathrm{mg} \mathrm{Ti} / \mathrm{kg}$ tissue have been detected. These

Table $2 \mathrm{Ti}$ and $\mathrm{TiO}_{2}$ particles in human (post mortem 4\% formaldehyde fixed) liver and spleen

\begin{tabular}{|c|c|c|c|c|c|c|c|c|c|c|}
\hline \multirow[b]{2}{*}{ Human } & \multirow{3}{*}{ Tissue } & \multirow{3}{*}{$\begin{array}{l}\text { Total Ti } \\
\text { mg/kg }\end{array}$} & \multicolumn{2}{|c|}{$\mathrm{TiO}_{2}$ (Particles) } & \multirow{2}{*}{$\begin{array}{l}\text { Ti in particles }{ }^{a} \\
\text { min - max }\end{array}$} & \multirow{3}{*}{ Tissue } & \multirow{3}{*}{$\begin{array}{c}\text { Total Ti } \\
\text { mg/kg }\end{array}$} & \multicolumn{2}{|c|}{$\mathrm{TiO}_{2}$ (Particles) } & \multirow{2}{*}{$\begin{array}{l}\text { Ti in particles }{ }^{a} \\
\text { min - max }\end{array}$} \\
\hline & & & size range & $\begin{array}{l}\text { number of } \\
\text { particles }\end{array}$ & & & & size range & $\begin{array}{l}\text { number of } \\
\text { particles }\end{array}$ & \\
\hline subject & & & $\mathrm{nm}$ & $10^{9} / \mathrm{kg}$ tissue & $\mathrm{mg} / \mathrm{kg}$ tissue & & & $\mathrm{nm}$ & $10^{9} / \mathrm{kg}$ tissue & mg/kg tissue \\
\hline 1 & Liver & 0.04 & $85-320$ & $2.3-7.2$ & $0.01-0.04$ & Spleen & 0.1 & $90-580$ & $5.7-18$ & $0.06-0.2$ \\
\hline 2 & Liver & 0.09 & $90-440$ & $6.6-21$ & $0.08-0.3$ & Spleen & 0.4 & $90-420$ & $18-56$ & $0.1-0.4$ \\
\hline 3 & Liver & $<$ LODt & $<$ LODs & $<$ LODn & $<$ LODC & Spleen & 0.02 & $85-370$ & $1.2-3.8$ & $0.01-0.04$ \\
\hline 4 & Liver & 0.05 & $85-550$ & $1.4-4.4$ & $0.03-0.1$ & Spleen & 0.09 & $85-320$ & $2.8-8.8$ & $0.01-0.02$ \\
\hline 5 & Liver & $<\mathrm{LODt}$ & $<$ LODs & $<$ LODn & $<$ LODC & Spleen & 0.03 & $85-520$ & $1.5-4.7$ & $0.02-0.07$ \\
\hline 6 & Liver & 0.03 & $85-380$ & $2.1-6.6$ & $0.01-0.04$ & Spleen & 0.02 & $85-350$ & $1.3-4.1$ & $0.01-0.04$ \\
\hline 7 & Liver & $<\mathrm{LODt}$ & $85-370$ & $1.3-4.1$ & $0.01-0.02$ & Spleen & 0.02 & $<$ LODs & $<$ LODn & $<\mathrm{LODC}$ \\
\hline 8 & Liver & 0.02 & $<$ LODs & $<$ LODn & $<$ LODC & Spleen & $<$ LODt & $<$ LODs & $<$ LODn & $<$ LODC \\
\hline 9 & Liver & $<$ LODt & $<$ LODs & $<$ LODn & $<$ LODC & Spleen & 0.2 & $85-410$ & $9.3-29$ & $0.08-0.3$ \\
\hline 10 & Liver & $<$ LODt & $<$ LODs & $<$ LODn & $<$ LODC & Spleen & 0.02 & $85-360$ & $2.1-6.6$ & $0.01-0.04$ \\
\hline 11 & Liver & 0.04 & $85-450$ & $2.6-8.1$ & $0.02-0.07$ & Spleen & 0.03 & $90-420$ & $3.2-10$ & $0.02-0.07$ \\
\hline 12 & Liver & 0.02 & $<$ LODs & $<$ LODn & $<$ LODC & Spleen & 0.04 & $90-720$ & $2.1-6.6$ & $0.05-0.2$ \\
\hline 13 & Liver & $<\mathrm{LODt}$ & $90-440$ & $1.0-3.1$ & $0.03-0.1$ & Spleen & 0.02 & $90-390$ & $2.3-7.2$ & $0.03-0.10$ \\
\hline 14 & Liver & $<\mathrm{LODt}$ & $<$ LODs & $<$ LODn & $<\mathrm{LOD}$ & Spleen & 0.03 & $90-430$ & $2.7-5.3$ & $0.03-0.1$ \\
\hline \multirow[t]{7}{*}{15} & Liver & $<\mathrm{LODt}$ & $<$ LODs & $<$ LODn & $<$ LODC & Spleen & 0.04 & $90-500$ & $2.4-7.5$ & $0.03-0.1$ \\
\hline & $n>\operatorname{lod}$ & 7 & $7-7$ & $7-7$ & $7-7$ & & 14 & $13-13$ & $13-13$ & $13-13$ \\
\hline & average & $0.04^{b}$ & $86-421$ & $2-8$ & $0.03-0.1$ & & $0.08^{c}$ & $88-445$ & $4-13$ & $0.04-0.1$ \\
\hline & mode & 0.04 & $85-440$ & - & $0.01-0.04$ & & 0.02 & $85-420$ & $2-7$ & $0.01-0.04$ \\
\hline & stdev & 0.02 & $2-74$ & $2-6$ & $0.02-0.1$ & & 0.1 & $3-110$ & $5-15$ & $0.03-0.11$ \\
\hline & $\min$ & 0.02 & $85-320$ & $1-3$ & $0.01-0.02$ & & 0.02 & $85-320$ & $1-4$ & $0.01-0.02$ \\
\hline & $\max$ & 0.09 & $90-550$ & $7-21$ & $0.08-0.3$ & & 0.4 & $90-720$ & $18-56$ & $0.1-0.4$ \\
\hline
\end{tabular}

Particle $\mathrm{TiO}_{2}$ concentrations are reported as measured (min) and after correction for the analytical recovery (max). All concentrations are corrected for total concentrations in blanks $\left(0.05 \mathrm{mg} / \mathrm{kg}\right.$ ). LODt (total-Ti) $=0.01 \mathrm{mg} / \mathrm{kg} ;$ LODs (size) $=85 \mathrm{~nm}$; LODn (number) $=0.8 \times 10^{9} / \mathrm{kg} ; \mathrm{LODc}($ calculated Ti in particles) $=$ $0.005 \mathrm{mg} / \mathrm{kg}$; ${ }^{\mathrm{a}}$ calculated Ti in particle, calculated according to Laborda et al. [21] and Peters et al. ${ }^{\mathrm{b}}$ if calculated with $1 / 2$ LOD for samples below LOD, average total- $\mathrm{Ti}=0.02 \mathrm{mg} / \mathrm{kg}$; if calculated with $1 / 2 \mathrm{LOD}$ for samples below LOD, average total-Ti $=0.07 \mathrm{mg} / \mathrm{kg}$ 
concentrations have been measured using X-ray fluorescence and neutron activation analysis, while we used HR-ICPS [25, 26].

The blank-corrected limit of detection (LOD) total $\mathrm{Ti}$ was $0.01 \mathrm{mg} / \mathrm{kg}$ tissue, while the analytical recovery for total-Ti was $112 \pm 34 \%$, which is in the range of accepted analytical standards [20]. None of the specific steps in the tissue and sample preparation contributed to the blank total-Ti. Two human subjects carried a titanium implant, the total-Ti content in liver and spleen of these subjects was comparable to those observed in the liver and spleen in other subjects.

\section{Particle measurements}

The presence of $\mathrm{TiO}_{2}$ particles in the tissues is evidenced by the characteristic spikes in the time scans of the spICP-HRMS analysis of liver and spleen samples (Fig. 1a, b). $\mathrm{TiO}_{2}$ particles were detected in $7 / 15$ liver and 13/15 spleen samples (Table 2). The smallest $\mathrm{TiO}_{2}$ particle that can be detected with this method $\left(\mathrm{LOD}_{\text {size }}\right)$ in these tissues is $85 \mathrm{~nm}$. The number-based $\mathrm{TiO}_{2}$ particle size distributions in liver and spleen were comparable and had a size range of 85-550 and 85-720, respectively (Table 2 and Fig. 1c). SpICP-HRMS does not allow a further characterisation of the particles being
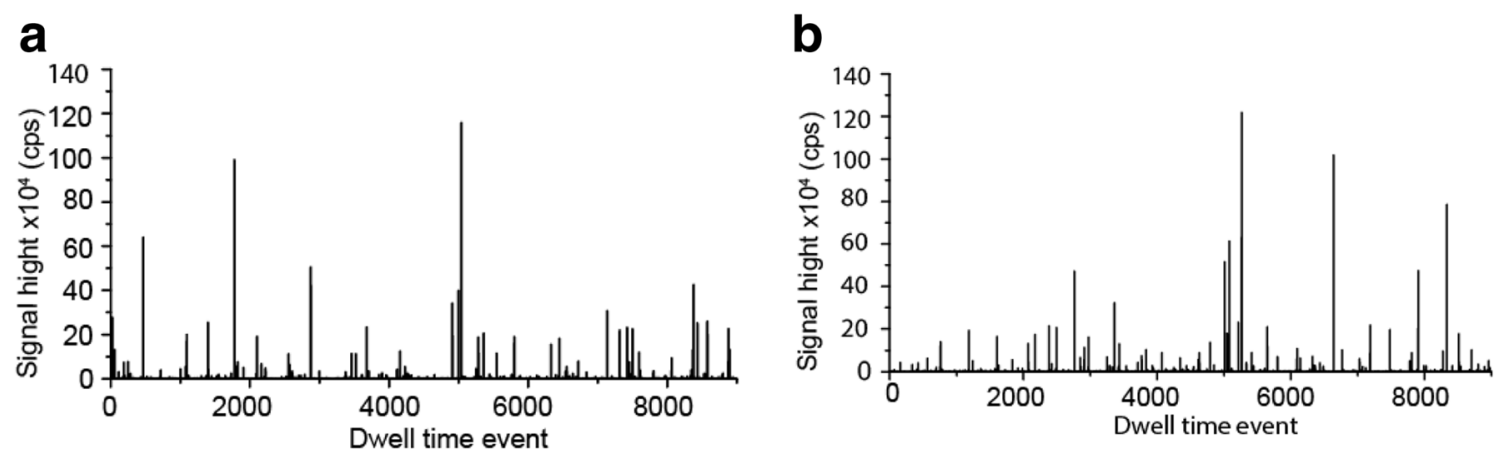

C

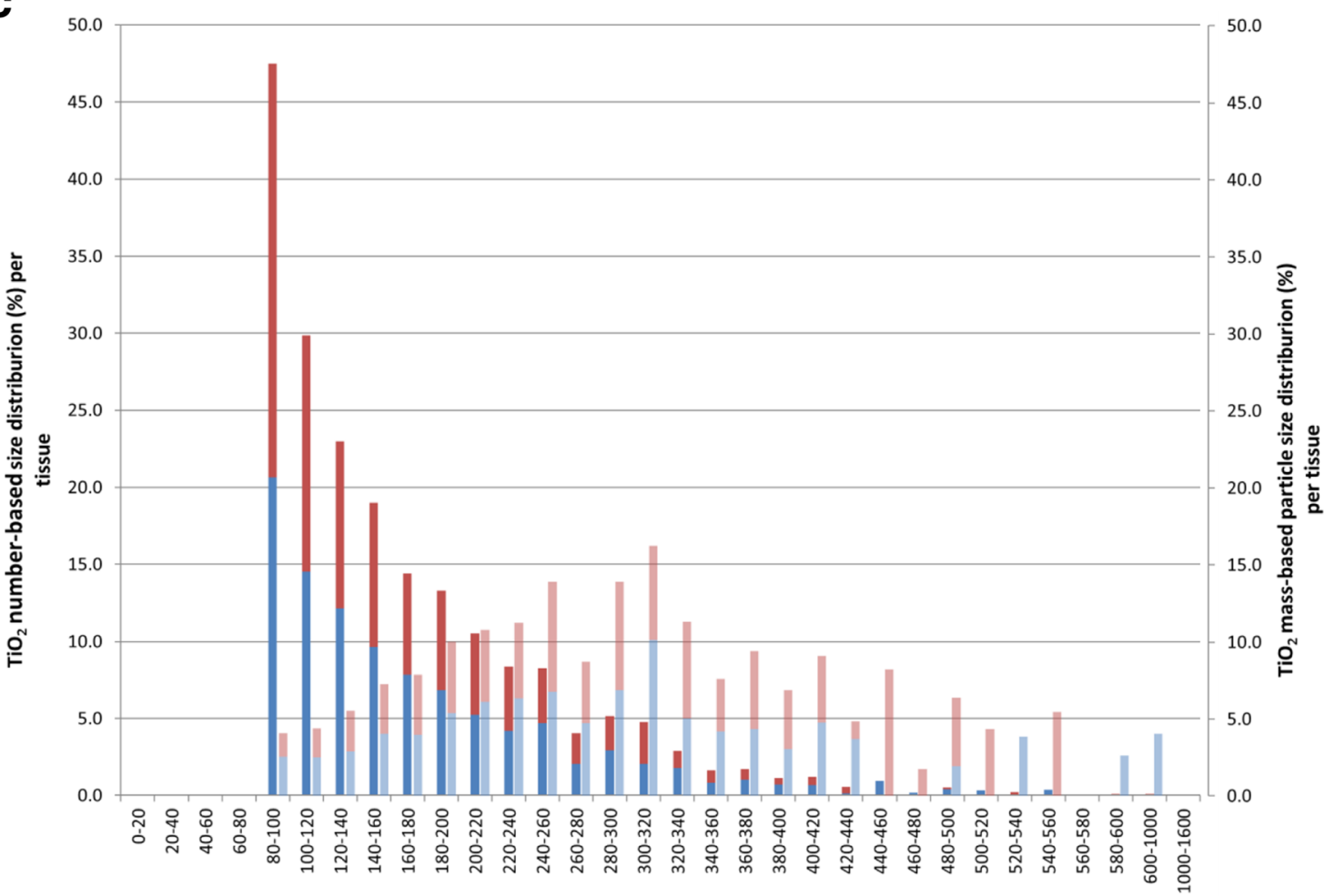

Fig. $1 \mathrm{TiO}_{2}$ particles in human (post mortem) liver and spleen. Time scans of the spICP-HRMS analyses of a liver sample (a) and spleen sample (b). The number of spikes in the time scan is directly proportional to the number of particles in the sample. The signal height of the peaks is directly proportional to the particle's mass from which the equivalent spherical particle size is calculated [22, 23]. c The calculated number-based particle size distribution (left axis and dark colours) and the calculated mass-based particle size distribution (right axis and light colours). Since the particle size distribution in liver (red bars) and spleen (blue bars) are very similar, they are stacked 
present as agglomerates, aggregates or primary particles. In the tissues, $24 \%$ of the $\mathrm{TiO}_{2}$ particles in the numberbased size distribution was $<100 \mathrm{~nm}$, but this fraction may be underestimated considering the $\mathrm{LOD}_{\text {size }}$ of $85 \mathrm{~nm}$.

The $\mathrm{TiO}_{2}$ particle mass concentration in liver ranged from 0.01 to $0.3 \mathrm{mg} \mathrm{Ti} / \mathrm{kg}$ tissue $\left(1.0 \times 10^{9}\right.$ to $21 \times 10^{9}$ $\mathrm{TiO}_{2}$ particles $/ \mathrm{kg}$ tissue) (Table 2). In spleen, this concentration ranged from 0.01 to $0.4 \mathrm{mg} \mathrm{Ti} / \mathrm{kg}$ tissue $\left(1.2 \times 10^{9}\right.$ to $56 \times 10^{9} \mathrm{TiO}_{2}$ particles $/ \mathrm{kg}$ tissue). The $\mathrm{LOD}_{\text {particle-number }}$ in the tissue matrix is $0.8 \times 10^{9}$ particles per kg tissue. The analytical recovery of $\mathrm{TiO}_{2}$ particles by enzymatic digestion of the matrix is $32 \pm 7 \%$. This low analytical recovery is in accordance with best international practices for this sample preparation and detection technique [27]. Because of the low analytical recovery, the $\mathrm{Ti}$ concentration of the particles is presented both as a minimum (not corrected for analytical recovery), and a maximum (corrected for analytical recovery) (see Table 2).

The total-Ti values are in general within this $\mathrm{Ti}$ concentration range in the particles, Furthermore, tissues with high total-Ti concentrations also contained high $\mathrm{TiO}_{2}$ particle concentrations, and vice versa. Based on the maximum $\mathrm{Ti}$ concentration values in particles, on average minimally 51\% (liver) and 67\% (spleen) of total $\mathrm{Ti}$ is present in these tissues as particle. Taking into account the analytical recovery $(32 \pm 7 \%)$ and the $\mathrm{LOD}_{\text {size }}$ $(85 \mathrm{~nm})$ for the particles measurements, we assume all total $\mathrm{Ti}$ is present as particles.
We did not observe a correlation in the abundance of the $\mathrm{TiO}_{2}$ particles in liver and spleen from the same subjects, while this would be expected based on the shared external exposure. The reason for this lack of correlation may be related to inter-individual differences in the various involved biodistribution processes.

Lastly, small tissue grains of liver and spleen from two subjects were analysed using SEM-EDX to visualize the $\mathrm{TiO}_{2}$ particles. As shown in Fig. 2, the observed particles are composed of $\mathrm{Ti}$ and oxygen and are present as an aggregate or agglomerate, consisting of smaller primary particles of 75-150 nm. Presence of $\mathrm{Ti}$ was also confirmed semi-quantitatively by EDX analysis in dry-ashed liver and spleen samples (Fig. 2d).

Together, these analyses show that approximately all $\mathrm{TiO}_{2}$ is present as particles in human liver and spleen, with sizes ranging 85-550 and 85-720, respectively (upper size limit of detection was $>1.5 \mu \mathrm{m}$ ). Probably also smaller particles are present, however these cannot be detected with the current methods. The SEM analysis of the particles suggests that the larger particles consist of smaller primary particles. Therefore, for the purpose of risk assessment, we assume that all $\mathrm{Ti}$ is ultimately present as $\mathrm{TiO}_{2}$ nanoparticles.

\section{Risk assessment}

In a next step, the total $\mathrm{TiO}_{2}$ levels in liver and spleen were compared to the toxicologically safe tissue levels for $\mathrm{TiO}_{2}(0.14 \mathrm{mg} / \mathrm{kg}$ for spleen and

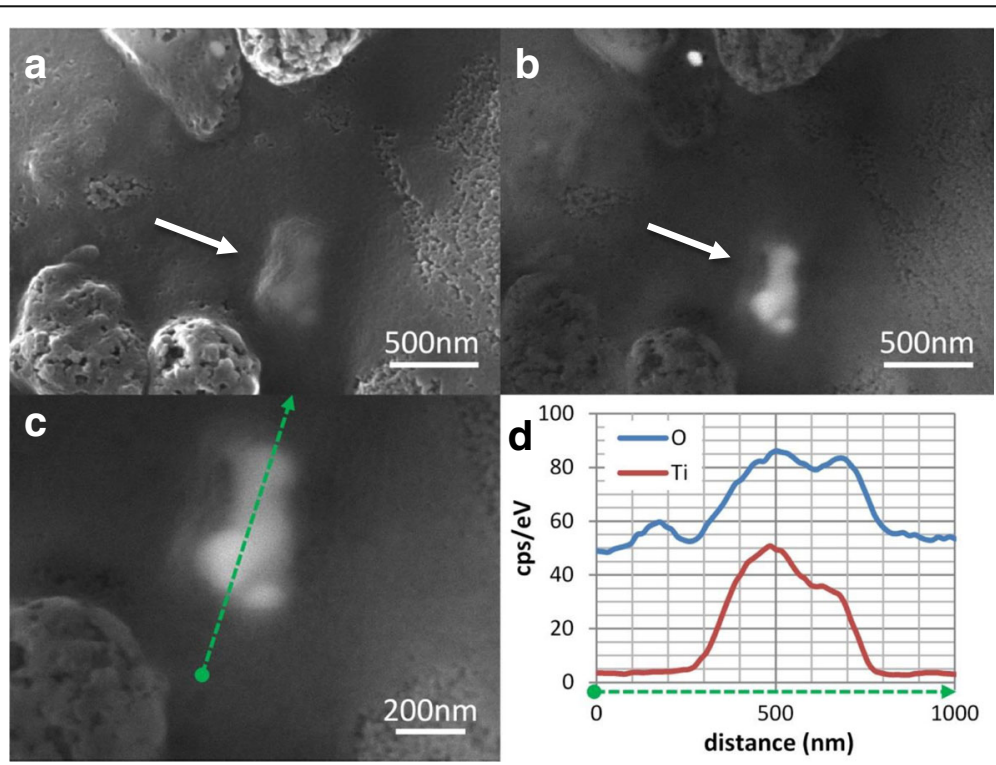

Fig. 2 SEM characterization of detected $\mathrm{TiO}_{2}$ particles in a dried liver sample. a The secondary electron microscope image shows a $\mathrm{TiO}_{2}$ agglomerate below the surface of the liver tissue (arrow). $\mathbf{b}$ The backscattered electron image reveals the spherically shaped primary particles within the agglomerate (arrow), with diameters between 75 and $150 \mathrm{~nm}$; (c) illustrates the path of the EDX line scan across the aggregate in the same image at higher magnification; (d) demonstrates the presence of $\mathrm{TiO}_{2}$ based on the corresponding increase of response for $\mathrm{Ti}$ (red line) and oxygen (blue line) at the position of the particle. This forms a clear indication that the detected particle is indeed $\mathrm{TiO}_{2}$ 
$0.008 \mathrm{mg} / \mathrm{kg}$ for liver), as reported earlier [14]. For liver, the measured $\mathrm{TiO}_{2}$ concentrations are all below the level where effects occurred in animals, which were the occurrence of liver edema and liver enzyme level changes. However, the seven measurements $>$ LOD are above the level at which effects may occur in humans (Fig. 3). For the estimation of the safe level in humans, interspecies differences were considered and sensitive subpopulations were accounted for, which would include children, elderly, and diseased people (see also Additional file 1). It can therefore not be excluded that the observed liver levels lead to adverse effects in humans, such as a liver functioning less well, leading to e.g. less detoxification of substances in the blood, and less albumin production. For spleen, it is unlikely that adverse effects will occur in humans as the measured levels are distributed around the estimated safe levels (please note that in the key toxicological study [28], no adverse effects were reported, thus the highest tested dose was used here [14] (see also Additional file 2).

\section{Discussion}

The $\mathrm{TiO}_{2}$ particles observed in the human liver and spleens may have entered the body through dermal, inhalatory or oral exposure. No data on exposure, and thus neither on exposure route, of the subjects included in this study during life is available. However, dermal uptake of $\mathrm{TiO}_{2}$ particles is unlikely, as $\mathrm{TiO}_{2}$ particles do not penetrate the (intact) human skin $[17,29]$. It is likely that inhalatory uptake can be neglected as the chance is small that these people (all) had occupations with $\mathrm{TiO}_{2}$ exposure through air. In addition, the estimated maximal non-occupational exposure through this route is $4.5 \mu \mathrm{g}$ $\mathrm{Ti} /$ day (with an average of $0.75 \mu \mathrm{g} \mathrm{TiO}_{2} /$ day; based on the $\mathrm{Ti}$ concentrations in non-occupational settings of $0.01-0.1 \mu \mathrm{g} / \mathrm{m}^{3}$ ) [30]. Furthermore, most of these inhaled $\mathrm{TiO}_{2}$ particles are eliminated from the lungs by mucociliary clearance in the ciliated part of the lungs, and subsequently swallowed, as seen in some studies [31, 32]. Probably, most human subjects followed a West European diet and used toothpaste, which may result in a mean oral intake of $0.06-5.5 \mathrm{mg} \mathrm{TiO} / 2 / \mathrm{kg}$ body weight/ day $[3,10,33,34]$. Recent human volunteer studies indicate the systemic uptake following ingestion of $\mathrm{TiO}_{2}$ particles $[8,9]$. Strikingly, the size range of the $\mathrm{TiO}_{2}$ particles in the human livers and spleens (i.e. 86-421 and 88-445 nm, respectively) falls within that of the $\mathrm{TiO}_{2}$ particles in food products (30-600 nm diameter [2]). In conclusion, intestinal exposure, e.g. from food, toothpaste and supplements, but also from any inhaled and swallowed particles, is the most likely source of the $\mathrm{Ti}$ and $\mathrm{TiO}_{2}$ particles as found in the liver and spleens of these 15 subjects. This justifies our comparison with safe tissue levels derived from oral toxicity studies.

The current study shows that both the element $\mathrm{Ti}$ and $\mathrm{TiO}_{2}$ particles are present in post mortem fixed human liver and spleen and that health risks from liver damage due to oral exposure to $\mathrm{TiO}_{2}$ still cannot be excluded, especially in elderly people. Clearly, some issues as
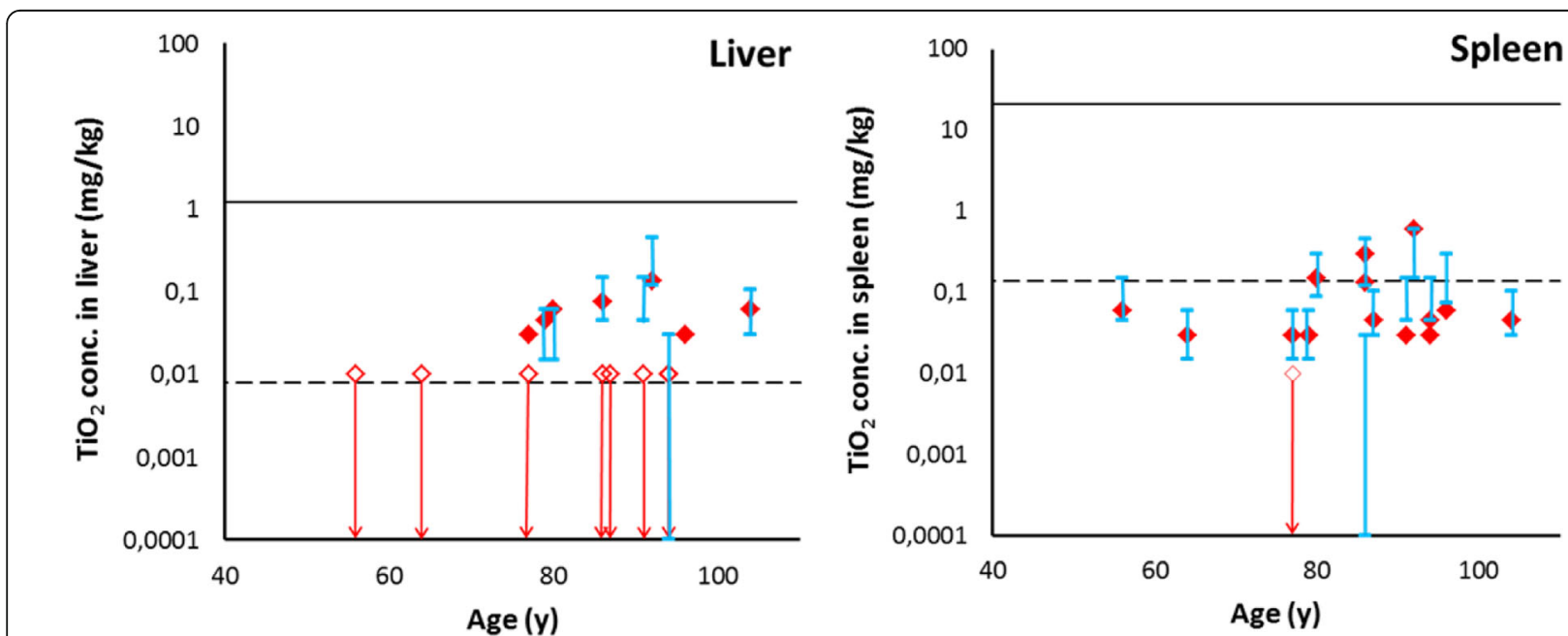

Fig. 3 Observed liver and spleen concentrations compared to toxicological effect levels. Measured total Ti (expressed as $\mathrm{TiO}_{2}$ to enable comparison, red diamonds) and $\mathrm{TiO}_{2}$ particle concentrations (blue ranges) in human liver and spleen are plotted against age, together with liver or spleen concentrations that are relevant for risk assessment (black lines). Open diamonds and arrows represent the possible levels in the samples where the Ti level was below the limit of detection (LOD). Measured particle concentrations are given as a range between the minimum possible level (no correction for the analytical recovery) and the maximum possible level (corrected for the analytical recovery). The solid black line represents the organ level at the No Observed Adverse Effect Level (NOAEL) in the animal study, i.e. the highest level at which no adverse effect was observed. The dashed black line represents the organ level below which no effects are expected in humans, considering several uncertainties in the animal data 
addressed in Heringa et al. [14] remain unresolved, like the limitations in the toxicological data set and the impact that different forms of $\mathrm{TiO}_{2}$, with different size [35], surface properties or crystalline structure can have on the observed toxicity. In addition, the available organs for this study were, understandably, limited to relatively older people and their $\mathrm{TiO}_{2}$ exposure and health condition is not known. Recently, concern has been raised on the potential contribution of $\mathrm{TiO}_{2}$ on tumor formation in the intestine $[36,37]$. More information on the adverse effects of $\mathrm{TiO}_{2}$ particles, including potential effects on liver as well as on potential carcinogenic induction and promotion in the gastrointestinal tract, would reduce the uncertainties in the current risk assessment.

\section{Conclusion}

Using two independent particle characterization techniques, we unequivocally show the presence of $\mathrm{TiO}_{2}$ particles in (post mortem) human liver and spleen and provide quantitative data on the total human organ burden of $\mathrm{TiO}_{2}$ particles for the first time. Particles with a size between 85 and $720 \mathrm{~nm}$ were found in tissue, of which at least $24 \%$ was smaller than $100 \mathrm{~nm}$. This unique study thereby adds another critical piece to the risk assessment puzzle for $\mathrm{TiO}_{2}$ (nano)particles, showing that health risks related to liver damage (i.e. liver edema and liver enzyme changes) due to $\mathrm{TiO}_{2}$ particles still cannot be excluded.

\section{Endnotes}

${ }^{1}$ Values reported here are based on values above LOD, excluding the values below LOD.

\section{Additional file}

Additional file 1: Supplementary Information for "Detection of titanium particles in human liver and spleen and possible helath implications". (DOCX $130 \mathrm{~kb})$

\section{Abbreviations}

(FEG-)SEM-EDX: (field emission gun) scanning electron microscopy - energy dispersive X-ray; (sp)ICP-HRMS: (single particle) inductively coupled plasma high resolution mass spectrometry; ADI: Acceptable daily intake;

EDTA: Ethylenediaminetetraacetic acid; EFSA: European Food Safety Authority; HF : Hydrofluoric acid; $\mathrm{HNO}_{3}$ : Nitric acid; IUPAC: International Union of Pure and Applied Chemistry; LOD: Limit of detection; NaCl: Sodium chloride; NOAEL: No observed adverse effect level; PE : Polyethylene; PFA: Perfluoroalkoxy; SDS: Sodium dodecyl sulphate; Ti: Titanium; $\mathrm{TiO}_{2}$ : Titanium dioxide

\section{Acknowledgements}

Our deep respect goes to the 15 people who donated their bodies to science post mortem and thus enabled these analyses. We thank J. Castenmiller and D. van Aken of the NWWA and K. Planken of the Ministry of Health, Welfare and Sport for their support and fruitful discussions. We thank P. Nobels and W. Schuurmans of Wageningen University Research for their assistance with the ICP-HRMS analysis. Rob Vandebriel (RIVM) is acknowledged for his help on evaluating the spleen effects reported in recent studies, Wim de Jong, Adrienne Sips and Joke Herremans (RIVM) for their useful comments on the paper.

\section{Funding}

The research was commissioned and financed by The Netherlands Food and Consumer Product Safety Authority (NWWA) and the Ministry of Economic Affairs.

\section{Availability of data and materials}

All relevant data are included in the manuscript and supporting information. These are also available from the authors upon request.

\section{Authors' contributions}

$\mathrm{MH}, \mathrm{RP}, \mathrm{AO}, \mathrm{PVK}$, and $\mathrm{HB}$ conceived and designed the experiments. RB contributed sample materials. RP, MvdL, and AU supervised and analysed experiments and data. PT performed SEM-EDX measurements. JvE made the kinetic models for the risk assessment. $\mathrm{MH}$ and $\mathrm{AO}$ performed the risk assessment. MH, RP, MvdL, AO, and HB co-wrote the paper. All authors read and approved the final manuscript.

\section{Ethics approval}

Written informed consent was obtained during life from the people of which the organs were used in this study, that allowed the use of their entire bodies for educational and research purposes. All ethical regulations concerning the use of these organs were followed, and approval for this specific scientific use was obtained from the board of University Medical Center Utrecht.

\section{Competing interests}

The authors declare that they have no competing interests.

\section{Publisher's Note}

Springer Nature remains neutral with regard to jurisdictional claims in published maps and institutional affiliations.

\section{Author details \\ ${ }^{1}$ National Institute for Public Health and the Environment (RIVM), Bilthoven, The Netherlands. ${ }^{2}$ RIKILT, Wageningen University \& Research, Wageningen, The Netherlands. ${ }^{3}$ Department of Anatomy, University Medical Center Utrecht, Utrecht, The Netherlands. ${ }^{4}$ TNO Earth, Life and Social Sciences, Utrecht, The Netherlands. ${ }^{5}$ Present address: Division of Toxicology, Wageningen University, Wageningen, The Netherlands.}

Received: 1 December 2017 Accepted: 8 March 2018

Published online: 11 April 2018

References

1. Piccinno F, Gottschalk F, Seeger S, Nowack B. Industrial production quantities and uses of ten engineered nanomaterials in Europe and the world. J Nanopart Res. 2012;14(9):1109.

2. Peters RJ, van Bemmel G, Herrera-Rivera Z, Helsper HP, Marvin HJ, Weigel $S$, et al. Characterization of titanium dioxide nanoparticles in food products: analytical methods to define nanoparticles. J Agric Food Chem. 2014;62(27):6285-93.

3. Rompelberg C, Heringa MB, van Donkersgoed G, Drijvers J, Roos A, Westenbrink $S$, et al. Oral intake of added titanium dioxide and its nanofraction from food products, food supplements and toothpaste by the Dutch population. Nanotoxicology. 2016;10(10):1404-14.

4. ( $\mathrm{NCl}) \mathrm{NCl}$. Bioassay of titanium dioxide for possible carcinogenicity, Carcinogenesis Technical Report Series. Maryland: Bethesda. p. 1979

5. Warheit DB, Donner EM. Risk assessment strategies for nanoscale and finesized titanium dioxide particles: recognizing hazard and exposure issues. Food Chem Toxicol. 2015;85:138-47.

6. FAO. Titanium Dioxide. In: Chemical and Techncial assessment; 2006.

7. JECFA. Specifications for the identitity and purity of food additives and their toxicological evaluation. Some food colours, emulsifiers, stabilizers, anticaking agents, and certain other substances. 13th report of the JECFA. In: World Health Organisation Techncial Report Series, No 445; FAO Nutrition Meetings Report Series, No 46. Rome; 1970.

8. Pele LC, Thoree V, Bruggraber SF, Koller D, Thompson RP, Lomer MC, et al. Pharmaceutical/food grade titanium dioxide particles are absorbed into the bloodstream of human volunteers. Part Fibre Toxicol. 2015;12:26.

9. Bockmann J, Lahl H, Eckert T, Unterhalt B. Blood titanium levels before and after oral administration titanium dioxide. Pharmazie. 2000;55(2):140-3. 
10. EFSA. Re-evaluation of titanium dioxide (E 171) as a food additive. EFSA J. 2016;14(9)

11. Kreyling WG, Holzwarth U, Schleh C, Kozempel J, Wenk A, Haberl N, et al. Quantitative biokinetics of titanium dioxide nanoparticles after oral application in rats: part 2. Nanotoxicology. 2017;11(4):443-53.

12. Geraets L, Oomen AG, Krystek P, Jacobsen NR, Wallin H, Laurentie M, et al. Tissue distribution and elimination after oral and intravenous administration of different titanium dioxide nanoparticles in rats. Part Fibre Toxicol. 2014;1 1:30.

13. Bello D, Warheit DB. Biokinetics of engineered nano-TiO2 in rats administered by different exposure routes: implications for human health. Nanotoxicology. 2017;11(4):431-3

14. Heringa MB, Geraets L, van Eijkeren JC, Vandebriel RJ, de Jong WH, Oomen AG. Risk assessment of titanium dioxide nanoparticles via oral exposure, including toxicokinetic considerations. Nanotoxicology. 2016;10(10):1515-25.

15. Snyder WS, Cook MJ, Nasset ES, Karhausen LR, Parry Howells G, Tipton $\mathbb{H}$. Report of the task group of reference man. A report prepared by a task group of committee 2 of the international commission on radiological protection: The international Comission on Radiological Protection, Oxford; 1992.

16. Yukawa M, Suzuki-Yasumoto M, Amano K, Terai M. Distribution of trace elements in the human body determined by neutron activation analysis. Arch Environ Health Int J. 1980;35(1):36-44.

17. Shi H, Magaye R, Castranova V, Zhao J. Titanium dioxide nanoparticles: a review of current toxicological data. Part Fibre Toxicol. 2013;10:15.

18. Powell JJ, Faria N, Thomas-McKay E, Pele LC. Origin and fate of dietary nanoparticles and microparticles in the gastrointestinal tract. J Autoimmun. 2010;34(3):J226-33.

19. Peters R, Herrera-Rivera Z, Undas A, van der Lee M, Marvin H, Bouwmeester $H$, et al. Single particle ICP-MS combined with a data evaluation tool as a routine technique for the analysis of nanoparticles in complex matrices. J Anal Atomic Spectrom. 2015;30(6):1274-85.

20. Tassinari R, Cubadda F, Moracci G, Aureli F, D'Amato M, Valeri M, et al. Oral, short-term exposure to titanium dioxide nanoparticles in Sprague-Dawley rat: focus on reproductive and endocrine systems and spleen. Nanotoxicology. 2014;8(6):654-62.

21. Laborda F, Bolea E, Jimenez-Lamana J. Single particle inductively coupled plasma mass spectrometry: a powerful tool for nanoanalysis. Anal Chem. 2014;86(5):2270-8.

22. van Rossum CTM, Fransen HP, Verkaik-Kloosterman J, Buurma EM, Ocké MC. Dutch National Food Consumption Survey 2007-2010: diet of children and adults aged 7 to 69 years. Bilthoven: National Institute for Public Health and the Environment (RIVM); 2011.

23. Currie LA. Nomenclature in evaluation of analytical methods including detection and quantification capabilities (IUPAC recommendations 1995). In: Pure Appl Chem, vol. 671995: 1699.

24. Lee S, Bi X, Reed RB, Ranville JF, Herckes P, Westerhoff P. Nanoparticle size detection limits by single particle ICP-MS for 40 elements. Environ Sci Technol. 2014;48(17):10291-300.

25. Yukawa M, Amano K, Suzuki-Yasumoto M, Terai M. Distribution of trace elements in the human body determined by neutron activation analysis. Arch Environ Health. 1980;35(1):36-44.

26. National Research Council. Mineral tolerance of animals. second revised ed. Washington: National Academies Press; 2005.

27. Loeschner K, Braband MS, Sloth JJ, Larsen EH. Use of alkaline or enzymatic sample pretreatment prior to characterization og gold nanoparticles in animal tissue by single particle ICPMS. Anal Bioanal Chem. 2014;16:3845-51.

28. Wang Y, Chen Z, Ba T, Pu J, Chen T, Song Y, et al. Susceptibility of young and adult rats to the oral toxicity of titanium dioxide nanoparticles. Small. 2013;9(9-10):1742-52.

29. SCCS, Chaudhry Q. Opinion of the scientific committee on consumer safety (SCCS) - revision of the opinion on the safety of the use of titanium dioxide, nano form, in cosmetic products. Regul Toxicol Pharmacol. 2015;73(2):669-70.

30. IPCS (International Programme on Chemical Safety). Environmental Health Criteria 24_Titanium. Geneva: WHO; 1982. ISBN 9241540842.

31. Pujalte I, Dieme D, Haddad S, Serventi AM, Bouchard M. Toxicokinetics of titanium dioxide (TiO2) nanoparticles after inhalation in rats. Toxicol Lett. 2017:265:77-85

32. Kreyling WG, Holzwarth U, Haberl N, Kozempel J, Wenk A, Hirn S, et al. Quantitative biokinetics of titanium dioxide nanoparticles after intratracheal instillation in rats: part 3. Nanotoxicology. 2017;11(4):454-64.
33. Sprong C, Bakker M, Niekerk M, Venneman F. Exposure assessment of the food additive titantuim dioxide (E 171) based on use levels provided by the industry. Bilthoven: RIVM; 2015.

34. Weir A, Westerhoff $P$, Fabricius $L$, Hristovski $K$, von Goetz N. Titanium dioxide nanoparticles in food and personal care products. Environ Sci Technol. 2012:46(4):2242-50.

35. Laurent A, Harkema JR, Andersen EW, Owsianiak M, Vea EB, Jolliet O. Human health no-effect levels of $\mathrm{TiO} 2$ nanoparticles as a function of their primary size. J Nanopart Res. 2017;19(4):130.

36. Urrutia-Ortega IM, Garduno-Balderas LG, Delgado-Buenrostro NL, FreyreFonseca V, Flores-Flores JO, Gonzalez-Robles A, et al. Food-grade titanium dioxide exposure exacerbates tumor formation in colitis associated cancer model. Food Chem Toxicol. 2016;93:20-31.

37. Bettini S, Boutet-Robinet E, Cartier C, Comera C, Gaultier E, Dupuy J, et al. Food-grade $\mathrm{TiO} 2$ impairs intestinal and systemic immune homeostasis, initiates preneoplastic lesions and promotes aberrant crypt development in the rat colon. Sci Rep. 2017;7:40373.

\section{Submit your next manuscript to BioMed Central and we will help you at every step:}

- We accept pre-submission inquiries

- Our selector tool helps you to find the most relevant journal

- We provide round the clock customer support

- Convenient online submission

- Thorough peer review

- Inclusion in PubMed and all major indexing services

- Maximum visibility for your research

Submit your manuscript at www.biomedcentral.com/submit
Biomed Central 